\title{
Oil price volatility and macroeconomy: Tales from top two oil producing economies in Africa
}

\author{
Beyond Eagle* \\ *Corresponding author's email address: beyondeagle42@gmail.com
}

\section{A R T I C L E I N F O}

Received: 20-03-2017

Revised received: 26-07-2017

Accepted: 28-08-2017

Available online: 16-09-2017

Keywords:

E(GRACH);

Granger causality;

Macroeconomic performance;

Oil Price Volatility.

JEL Classification:

E6; E30, E31; L2.

\begin{abstract}
A B S T R A C T
This study examines the relationship between oil price volatility and macroeconomic performance in two top net oil exporting countries in Africa (Angola and Nigeria) using quarterly data from International Monetary Fund, Central Bank of Nigeria and Angola were used to carry out the empirical analysis. Using structural Vector Autoregressive Model (SVAR), E(GARCH) and Granger Causality test results shows that oil price volatility has marginal impact on growth rate of GDP in both countries. Both impulse response function and variance decomposition shows that shocks to exchange rate from oil price volatility was the highest i.e. exchange rate appreciates when oil price increases and depreciates when oil price reduces. The Granger causality test shows that the direction of causality between oil price volatility and macroeconomic variables in Nigeria was bi-directional while the relationship in Angola was unidirectional. Hence, both countries (Angola and Nigeria) should improve upon the refining capacity of their crude oil. Also, economic diversification should be strengthening to promote indigenous production to reduce importation of those goods that could be endogenously produced.
\end{abstract}

(C) 2017 The Authors. This is an open access article under the terms of the Creative Commons Attribution License 4.0, which allows use, distribution and reproduction in any medium, provided the original work is properly cited.

\section{Background to the study}

Crude oil represents one of the most important natural resources and it has the largest commodity market in the world. Unlike other commodities, oil is one of the few or the only production input that have both symmetric and asymmetric effects on macroeconomic performance. To a large extent, its fluctuation can lead to a business cycle. (Gonzalez and Nabiyev, 2009). These fluctuations are more pronounced than they were in the 1970s, creating unpredictable consequences. On the other hand, crude oil price fluctuation from 1970s to 2011 has been increasingly erratic with the volatility being more erratic since 2002. Oil price volatility dampens growth through different channels, from an increase in production cost to inflation expectations. Besides, oil price increase can translate into higher transportation, production, and heating costs, which can put a drag on corporate earnings, it can also affect price stability, firm profitability and a country's financial system stability (Li \& Zhao, 2011).

Furthermore, the impact of oil price shock and volatility on the output growth of net oil exporting nations are not the same with the impact on net oil importing nations. For instance, oil price increase might be considered bad for oil-importing nations but good news for oil-exporting nations. The reverse might be expected for oil price decreases. The immediate effect of positive oil price shocks is to increase the cost of production for oil importing countries. This is likely to reduce the output, and its magnitude depends on the shape of the aggregate demand curve. Higher oil prices lower disposable income and this decreases consumption. Once the oil price increases are perceived as permanent, private investments also decrease. Moreover, if the shocks are perceived as persistent, oil is used less in production, capital and labour productivity both decrease and potential output falls, From empirical studies such as Rasche and (Tafom, 1977, 1981),( Darby, 1982); (Mork, 1989) justify the rising oil 
prices reduce output and increase inflation. Based on this, tax revenue reduces and budget deficit increase. Oil price changes also affect trade and exchange rates. When oil prices increase, the inelastic demand curve for oil means total spending on oil imports increases. This puts pressure on the exchange rate and depreciate the local currency. This reduction in the value of currency may further reduce economic performance.

The level at which oil price changes engender macroeconomic performance continue to attract theoretical and empirical discussions especially in developing nations. In recent time, the debate has been given impetus in African countries. The basis of this agitation is due to the argument that the seemingly steady growth that has been recorded over the past decades has not translated to a reasonable level of output growth. Furthermore, the sharp drop in oil prices since mid - 2008 till date has brought to the fore a different challenge whether oil exporters in African can sustain spending levels reached in previous years (Joseph, Festus 2013).

The impact (positive or negative) which oil price shocks/volatility could have on any economy depends on what part of the divide such economy falls into and of course the nature of such price change (either increase or decrease). However, eighty percent of oil producing countries in African qualifies as both as an oil exporters and importers by reason of the fact that they export crude oil, but imports refined petroleum products. Therefore, making a conclusive and authoritative statement on the impact of oil price shocks/volatility on them becomes so controversial (Iyoha \& Oriakhi, 2013). Therefore, investigating the consequences of oil price changes on output growth is particularly relevant in the case of oil producing countries in Africa. This is so because oil price changes influence their economies as exporters of crude oil and importers of refined petroleum products. It implies by simple logic that oil price change whatever the nature (either a rise or fall) can both benefit and hurt their economies at the same time. However, the crux of the problem lies in the fact that those oil producing countries in Africa continent entirely depend on oil over the years making their economies mono-product and this has triggered severe structural difficulties for their economies. The drastic reduction in world oil price since mid-2014 till date has equally called for the renewal in the investigating the relationship between oil price and output growth.

The analysis of macroeconomic effects of oil price has evolved along two distinct directions. On the one hand, a wave of empirical studies aimed at quantifying the effect of higher energy prices on macroeconomic variables. Most of these studies are purely empirical, lacked a solid theoretical basis and the results seems to depend essentially on the empirical approach, depending on estimation technique, the identification of oil price shocks, or the sample period. Very different conclusion can be arrived at. On the other hand, though theoretical studies examine the channel in which oil price might impart macroeconomic performance while these studies provide important insight regarding the transmission mechanism, the practical relevance of the different theoretical studies is not always clear, given the lack of empirical evidence. Therefore, this research work is an attempt at integrating both theoretical and empirical method to establish the relationship between oil price volatility and macroeconomic performance in two top net oil exporting countries in Africa.

The rest of the paper is structured as follows. This introductory section is followed by section two that discusses literature. Section three presents theoretical underpinning method and materials. Section four consists of the result and its analysis. Section five concludes the paper.

\section{Empirical review}

Several studies have been conducted on the relationship between oil price volatility and macroeconomic performance both in developed and developing economies. However, some of these studies are hereby presented.

(Arouri. Lathiani \& Nguyen 2011), investigated the six members of the Gulf Cooperation Council (GCC) from 2005-2010. The study employed VAR as the estimation techniques and found that the existence of significant return and volatility spillovers between world oil prices and GCC stock markets). To support this (Basher \& Sadorsky 2006), examined the relationship between oil price, risk and stock market returns in 21 emerging stock markets using co-integration and error correction as estimation techniques. The study found strong evidence that oil price risk impacts stock price returns in emerging markets economies negatively.

Also, in line with the previous studies (Park \& Ratti 2007), studied the U.S and 13 European countries using VAR and GARCH as estimation techniques to establish the relationship between oil price and output growth. The study found that increased volatility of oil prices significantly depressed real stock returns in the European countries, and that the contribution of oil price shocks to variability in real stock returns in U. S and most other countries was greater than that of other selected countries. They also found that increased in real oil price significantly raised the short-term interest rate in the U.S and eight out of 13 European countries within one or two months.

In another study (Agren, 2006), studied the weekly stock market data and oil price shocks for Germany, Japan, Sweden, the United Kingdom and the United states, from 1989 to 2005 employed VAR and ARCH as estimation techniques. The study discovered strong evidence of volatility spillover for Germany, Japan, and the U.K. Out of these countries, German and British stock markets seem to have an asymmetric volatility-response to oil shocks, meaning that positive shocks affect stock market volatility more than negative ones do.

Ramos and Veiga (2010) examined 43 stock markets and oil prices shocks both in some developed and developing economics. The study employed co-integration and error correction as estimation technique. The 
study found that in developed countries, oil price shocks depressed international stock markets, but oil price drops do not necessarily increase stock market returns, and that the volatility of oil prices had negative impact on international stock market returns, while emerging market returns were not sensitive to oil price variations.

To support the view of the previous authors, (Ito, 2008), investigated the impact of oil prices and monetary shocks on the levels of inflation, interest rate and real gross domestic product (GDP) for Russia during the period 1995:Q3-2007:Q4, using the co-integrated VAR model. The results showed that an oil price increase had positive effect on real GDP and inflation.

Erbil (2011), examined the cyclicality of fiscal policy in 28 oil-exporting countries during the period 19902009, using pooled OLS regression, Diff-GMM and Sys-GMM methods and found that all fiscal variables were strongly pro-cyclical in the full sample, but results were not the same across income groups. The results further showed that government expenditure was pro-cyclical in low and middle-income countries, while it was countercyclical in the high-income countries

(Husain, 2008), assessed the impact of oil price shocks on non-oil economic cycle in 10 oil-rich countries, including Oman over the period 1990-2007. The obtained results from a panel VAR showed that in countries where the oil sector was dominant, oil price changes affect the economic cycles through the fiscal policy channel.

To corroborate the above view, of Berument \& Ceylan Dogan (2010) studied the effects of oil price shocks on output growth (proxied by industrial production) for a selected Middle East and north Africa (MENA) countries, including Oman. They used several VAR models for the period 1960 to 2003. Their results showed that the impact of oil price on GDP of Iraq, Algeria, Kuwait, Oman, Jordan, Syria, Qatar, UAE and Tunisia were significantly positive, but not significant for other countries in their dataset. In line with the previous authors, (Bounchaout Ai-zeaud 2012) used a Vector Error Correction Model (VECM) and Variance Decomposition analysis (VD) to explore the effect of oil price volatility on Algerian economy during the period between 1980 and 2011. Their results revealed that oil price changes have a very limited impact on most macroeconomic variables in short run except a positive effect on inflation and negative influence on real exchange rate. However, in the long run, oil prices change had positively affected real GDP and inflation and had a negative effect on unemployment and real effective exchange rate.

In related study, Wakeford (2006), studied the impact of oil price shocks on the South African macro economy. The study traced the history of oil shocks and their impact on South Africa. The study used trend analysis as estimation technique. The findings revealed that while commodity exports-especially gold-provided an initial buffer, the economy was not immuned to sustained oil price shocks.

To buttress other studies, (Olomola 2006) investigated the impact of oil price shocks on aggregate economic activity (output, inflation, the real exchange rate and money supply) in Nigeria using quarterly data from 1970 to 2003. The findings revealed that contrary to previous empirical findings, oil price shocks did not affect output and inflation in Nigeria significantly. However, oil price shocks were found to significantly influence the real exchange rate. The author argued that oil price shocks may give rise to wealth effect that appreciates the real exchange rate and may squeeze the tradable sector, giving rise to the - Dutch-Disease.

(Akpan 2009), analysed the dynamic relationship between oil price shocks and economic activities. His findings showed that major oil price shocks significantly increased inflation and also directly increased real national income through higher export earnings, though part of this gain is seen to be offset by losses from lower demand for exports generally due to the economic recession suffered by trading partners. The findings also revealed a strong positive relationship between positive oil price changes and real government expenditures.

(Asaolu \& Oil 2012) used Co-integration analysis and Vector Error Correction Framework to analyze the impact of oil price on the Nigerian stock market performance. The study finds out that oil prices and stock market performance were tied together in the long run. A rise in price of oil leads to a decline in the return performance of the stock market.

(Somoye \& Ilo, 2008) examined the Nigerian stock market performance using vector-autoregressive (VAR). the study concluded that among the variables examined in the VAR model, the price of the Nigerian crude oil, exchange rate and the rate of inflation were the most significant macroeconomic variables influencing the aggregate stock market returns in Nigeria. Gunu Kilishi (2010) studied the impact of crude oil prices on key macroeconomic variable in Nigeria. They employed Vector Autoregressive model. The study concluded that crude oil prices had significant effect on the three key macroeconomic variables in Nigeria; GDP, money supply and unemployment.

The empirical literature reviewed above was far - reaching with respect to the relationship between oil price volatility and output growth both in oil importing and oil exporting countries. The results from the empirical reviewed seem to be contradictory. The results were based on different estimation techniques and sample periods. The earlier researchers employed ordinary least square as estimation technique with a very small sample period. The few studies that employed co-integration and error correction model either used Engel and Granger or Johansen and Juselius with different sample periods. The most recent studies that made used of Vector Autoregressive Distributive model were specific countries. Therefore, this study intends to run different structural vector Auto-regressive for each of the countries (Nigeria and Angola). 


\section{Empirical methodology}

\subsection{Theoretical framework}

Many of the theories relating to oil price dynamic and output growth are so conventional that we may not necessarily need to itemize them one after the other. However, our approach here is to use the most appropriate theory out of these theories to provide foundation for our model. The study finds the "Asymmetric theory of Economic Growth", the most relevant.

\subsubsection{The asymmetry theory of economic growth}

This theory was developed by Mark (1994), Ferderer, (1996) and Balke, (1996). The theory discusses the strength and the asymmetry in effect of oil price volatility on Output Growth. A member of this school, Ferderer (1996), provides a sufficient detailed reports of asymmetric mechanism between the influence of oil price volatility and output growth by concentrating on three possible ways, counter-inflationary monetary policy, sectoral shocks and uncertainly. From his study, he discovered a statistically significant relationship between increase in oil price and counter inflationary policy responses. This position of Balke (1996), was confirmed by the Federer submissions. The theory posits that monetary policy alone cannot adequately strengthen real impact of oil price volatility on output growth and that fiscal policy should be incorporated.

\subsection{Model specification}

Reference to the theoretical framework and with requirements for specifying Panel Vector Autoregressive Distributive Model, the equation below is hereby presented to examine the relationship between oil price volatility and output growth in ten top oil producing states in Africa.

$$
\begin{aligned}
& W O P_{i t}=\propto_{0}+\propto_{1} W O P_{i t-1 \ddot{\sigma} i t} \sum W O P_{i t} \\
& F I R_{i t}=\lambda_{0}+\lambda_{1} G D P_{i t-1}+\lambda_{2} W O P_{i t}+\sum G D P_{i t} \\
& E X R_{i t}=\beta_{0}+\beta_{1} W O P_{i t-1}+\beta_{2} E X R_{i t-1}+\beta_{3} C P I_{i t-1}+\beta_{4} M S_{i t-1}+\beta_{5} G D P_{i t-1}+\beta_{6} D I R_{i t-1}+\beta_{7} F R_{i t-1}+\sum E X R_{i t-1} \\
& C P I_{i t}=\mu_{0}+\mu_{1} W O P_{i t-1}+\mu_{2} E X R_{i t-1}+\mu_{3} C P I_{i t-1}+\mu_{4} M S_{i t-1}+\mu_{5} G D P_{i t-1}+\mu_{6} D I R_{i t-1}+\mu_{7} F R_{i t-1}+\sum C P I_{i t-1} \\
& M S_{i t}=\theta_{0}+\theta_{1} W O P_{i t-1}+\theta_{2} E X R_{i t-1}+\theta_{3} C P I_{i t-1}+\theta_{4} M S_{i t-1}+\theta_{5} G D P_{i t-1}+\theta_{6} D I R_{i t-1}+\theta_{7} F R_{i t-1}+\sum M S_{i t-1} \\
& G D P_{i t}=\gamma_{0}+\gamma_{1} W O P_{i t-1}+\gamma_{2} E X R_{i t-1}+\gamma_{3} C P I_{i t-1}+\gamma_{4} M S_{i t-1}+\gamma_{5} G D P_{i t-1}+\gamma_{6} D I R_{i t-1}+\gamma_{7} F R_{i t-1}+\sum G D P_{i t-1} \\
& D I R_{i t}=\kappa_{0}+\kappa_{1} W O P_{i t-1}+\kappa_{2} E X R_{i t-1}+\kappa_{3} C P I_{i t-1}+\kappa_{4} M S_{i t-1}+\kappa_{5} G D P_{i t-1}+\kappa_{6} D I R_{i t-1}+\kappa_{7} F R_{i t-1}+\sum D I R_{i t-1}
\end{aligned}
$$

\subsection{Measurement of oil price volatility}

$$
\begin{aligned}
& Y(E)=x(t) P+e(t) \\
& E(t) \phi_{c}-\widetilde{1} N\left[0, \sigma^{2}(t)\right] \\
& \sigma^{2}(t)={ }_{0}+{ }^{2}(t-1)+{ }_{j} \sigma^{2}(t-j)
\end{aligned}
$$

The implication of the above equation is that if the asymmetric effect is present $\theta<(>)$ o implying that negative (positive) shocks increase volatility more than positive (negative) shock of the same magnitude while if $\theta=0$, there is no asymmetric effect. The Schwartz information criterion (sic) as given above is used for the choice of best model sic $(\mathrm{g})=\log (\mathrm{EE} / \mathrm{n})+\mathrm{g} \log \mathrm{n} / \mathrm{n}$

\subsection{Model setup}

This study employed seven-variable in the SPVAR model. The model is segregated into three blocks namely: External sector, monetary sector and real sector blocks.

Foreign interest rate and world oil price represent external sector variables. Inflation rate, broad money supply and real interest rate and exchanged rate represent monetary sector variables. Finally, the growth rate of Gross Domestic Product constitutes real sector variables. 


\begin{tabular}{|c|c|c|c|c|c|c|c|c|c|}
\hline Fir & {$[1$} & 0 & $a_{13}$ & 0 & 0 & 0 & 0 & 0 & $a_{19}$ \\
\hline Wop & $a_{21}$ & 1 & 0 & $a_{24}$ & 0 & $a_{26}$ & 0 & 0 & 0 \\
\hline & 0 & 0 & 0 & 0 & 0 & 0 & 0 & & 0 \\
\hline $\operatorname{Inf}$ & $a_{41}$ & 0 & $a_{43}$ & 1 & 0 & $a_{46}$ & $a_{47}$ & 0 & 0 \\
\hline$M 2$ & $=$ & $a_{52}$ & 0 & $a_{54}$ & 1 & $a_{56}$ & $a_{57}$ & 0 & 0 \\
\hline Exr & $a_{61}$ & 0 & $a_{63}$ & 0 & 0 & 1 & 0 & $a_{68}$ & $a_{69}$ \\
\hline Dir & $a_{71}$ & $a_{72}$ & 0 & $a_{74}$ & 0 & $a_{76}$ & 1 & 0 & 0 \\
\hline GDPgr & 0 & $a_{82}$ & $a_{83}$ & 0 & $a_{85}$ & 0 & 0 & 1 & $a_{89}$ \\
\hline
\end{tabular}

\subsection{Identification of oil price shocks using S-VAR block exogeneity}

The model for this study is identical to those ones employed in prior studies. In most prior studies, researchers examined different barometers of oil price shocks in USA and small open economy and also measured the dynamic responses of macroeconomic variables to an oil price shock and also to external shocks.

However, Zhang (2011), in his study, he studied whether external shocks emanating from U.S played a vital role in the macroeconomic variables of East Asian countries. By ignoring constants and some other deterministic terms, the following SVAR is presented

$$
\beta(L) y(t)=\varepsilon(t)
$$

$\mathrm{Y}(\mathrm{t})$ is taken as observation, $\beta(L)$ is an $\mathrm{m} \times \mathrm{m}$ matrix polynomial in the lag operator $\mathrm{L}$, and $\varepsilon(t)$ is an $\mathrm{m} \times$ 1 vector of structural disturbances with

$$
\mathrm{y}(\mathrm{t})=\left[\begin{array}{l}
y_{1}(t) \\
y_{2}(t)
\end{array}\right], \quad \beta(L)=\left[\begin{array}{cc}
\beta_{11}(L) & \beta_{12}(L) \\
\beta_{21} & \beta_{22}(L)
\end{array}\right] \text { and } \varepsilon(t)=\left[\begin{array}{l}
\varepsilon_{1}(t) \\
\varepsilon_{2}(t)
\end{array}\right]
$$

The first block of the matrix represents macroeconomic variables and the second block represents monetary policy variables. The block exogeniety represents the restriction placed on $\beta^{21}=0$. The reason for this is that, it is assumed that domestic shocks do not affect the external sector variables, but domestic variable are taken to be influenced by external shocks. Therefore, in this model, the exogenous vector (WOP, and FIR) are taken to be external block while the endogenous vector (IMF, M2, EXR, GDPgr) is composed of both policy and non-policy variables which are also target variables. This is summarized below. A vector of structural shocks $\varepsilon=$ $\left[\begin{array}{l}\varepsilon_{1}(t) \\ \varepsilon_{2}(t)\end{array}\right]$ this is taken to be unrelated with $\mathrm{y}(\mathrm{t}-\mathrm{s})$ for $\mathrm{s}>0$ and to satisfy $\mathrm{E}[\varepsilon(t) \varepsilon(t) \mid y(t-s), s>0]=\mathrm{I}$ and $\mathrm{E}[\varepsilon(t) \mid y(t-s), s>0]=0$

Where $\varepsilon_{1}(\mathrm{t})$ is a vector of structural shocks to monetary variables and $\varepsilon_{2}(\mathrm{t})$ is a vector of structural shocks to monetary variables.

This study employs nine- variables SVAR model which is identical to that employed by prior studies. The model is segregated into three blocks namely: External sector, monetary sector and real sector blocks. Foreign interest rate, world oil price and trade openness represent external sector variables. Inflation rate, broad money supply and real interest rate and exchanged rate represent monetary sector variables. Finally, the growth rate of Gross Domestic Product and investment constitute real sector variables. By ignoring constants and some other deterministic terms, the SVAR is presented: $\mathrm{B}(\mathrm{L}) \mathrm{y}(\mathrm{t})=\varepsilon(t) . \mathrm{y}(\mathrm{t})$ is taken as observation, $\mathrm{B}(\mathrm{L})$ is an $\mathrm{M} \times \mathrm{M}$ matrix polynomial in the lag operator, $L$ and $\varepsilon(t)$ is an $M \times 1$ vector of structural disturbances. The first block of the matrix represents external sector variables; the second block constitutes the monetary sector variables while the last block represents real sector variables.

\section{Results}

This section presents the empirical results of the analysis starting with the time series properties of the variables used for the estimation.

\subsection{Unit root test for variables in Nigeria}

The results of the estimated models for the ADF stationarity test is presented in Table 1 in the table. From results, not all the variables of interest are stationary at level but became stationary after the first difference. This shows that the variables are integrated of order one. 1(1)

Table 1: Nigeria augmented dickey fuller test unit root test

\begin{tabular}{lrr}
\hline Variable & P Statistics & Order or integration \\
\hline GDPgr & -8.934567 & $1(1)$ \\
OCP & -12.45621 & $1(1)$ \\
NOCP & -11.52345 & $1(1)$ \\
IMPCPV & -11.23465 & $1(1)$ \\
EXCPV & -10.27345 & $1(1)$ \\
\hline
\end{tabular}




\begin{tabular}{lll}
\hline EXR & -7.664561 & $1(1)$ \\
IFR & -9.234562 & $1(1)$ \\
\hline
\end{tabular}

\subsection{Unit Root Test for variables in Angola}

The result of the ADF unit root test presented in Table 2 for Angola, shows the existence of nonstationarity in all the data series (except CPT) in level, as the absolute values of ADF test statistics, of the variables in level are less than the absolute (values of the) $95 \%$ critical value of the ADF statistic, thereafter, the variables are subjected to Stationarity Test at $1^{\text {st }}$ difference where they became stationary. Therefore, the variables of interest are integrated of order one 1 (1).

Table 2: Angola Augmented Dickey fuller unit Root Test.

\begin{tabular}{lrr}
\hline Variable & p-statistics & Order of integration \\
\hline GDPgr & -5.4142 & $1(1)$ \\
OCP & -8.8265 & $1(1)$ \\
NOCP & -4.7622 & $1(1)$ \\
IMPCPV & -6.3441 & $1(1)$ \\
EXCPV & -5.3121 & $1(1)$ \\
EXR & -4.8221 & $1(1)$ \\
IFR & -6.3311 & $1(1)$ \\
\hline
\end{tabular}

\subsection{Testing significance and Granger causality in Nigeria}

Table 3 shows the estimated values for pair wise tests of Granger Causality. From the first line result, the null hypothesis cannot be accepted. Therefore, oil price variable Granger causes economic growth that is used to proxy macroeconomic performance directly in Nigeria. The results from the table further shows that oil price volatility Granger causes consumer price index (CPI) at 5\% level of significance. Also, from the table, we cannot accept the null hypothesis therefore, we accept the alternative hypothesis that world oil price Granger causes real exchange rate in Nigeria. Considering the direction of causality between world oil price and money supply, the null hypothesis cannot still be accepted leaving us to accept the alternative hypothesis that world oil price Granger causes money supply in Nigeria, focusing attention on the direction of causality that exists between the only exogenous valuable (foreign interest rate) and world oil price: The Granger causality result shows that world oil price Granger causes foreign interest rate. Finally, the result on the table equally shows that the world oil price Granger causes domestic real interest rate.

Table 3: VAR lag order selection criteria.

\begin{tabular}{lrrrr}
\hline Lags & LR & AIC & SCE & HQ \\
\hline 0 & 11.23 & -7.68 & -7.33 & -8.21 \\
1 & 10.92 & -8.23 & -7.46 & -7.20 \\
2 & 28.21 & -7.31 & -8.21 & -7.18 \\
3 & 0.62 & -7.41 & -8.23 & -7.15 \\
4 & 0.72 & -7.88 & -7.03 & -8.22 \\
5 & 0.61 & -8.2 & -8.26 & -8.03 \\
6 & 11.22 & -8.3 & -7.32 & -8.21 \\
7 & 1.36 & -7.67 & -8.14 & -8.11 \\
8 & 5.61 & -8.22 & -7.03 & -7.64 \\
\hline
\end{tabular}

Conclusively, we can say emphatically that the interaction between world oil price and macroeconomic variables in Nigeria is significant with the direction of causality going at least one direction as showed by the pairwise Granger causality tests.

\subsection{Testing of significance and Granger causality for Angola}

The Granger causality test for Angola as presented in the Table 4 follows the same pattern with that of Nigeria. From the Granger causality results, world oil price Granger causes all the macroeconomic variable (consumer price index, exchange rate, real interest rate, and money supply) and foreign interest rate.

Table 4: variance decomposition of growth rate of gross domestic product for Nigeria.

\begin{tabular}{lrrr}
\hline Period & Standard error & Shock & Shock output \\
\hline 1 & 0.03462 & 40.30231 & 62.56211 \\
2 & 0.033461 & 40.64241 & 62.82345 \\
3 & 0.033441 & 40.53311 & 62.56221 \\
4 & 0.034562 & 40.63231 & 62.564567 \\
5 & 0.033132 & 40.52221 & 62.56332 \\
\hline
\end{tabular}




\begin{tabular}{lrrr}
\hline 6 & 0.032112 & 40.46221 & 62.56344 \\
7 & 0.031321 & 40.34562 & 62.564562 \\
8 & 0.033122 & 40.45521 & 62.564563 \\
9 & 0.033111 & 40.62233 & 62.566211 \\
10 & 0.032213 & 40.56211 & 62.56422 \\
\hline
\end{tabular}

Note: That structural factorization was performed

\subsection{Volatility measurement \\ 4.5.1 ARCH/GARCH result For Nigeria}

The regression shows the nature of the volatility of variance of the world oil price. Table 5 shows that the variance of world oil price has a mean variance of 3.83 and to establish the nature of the shock, the sum of the roots is expected to be less than one and close to unity. In this case, we say that it has a mean reverting process and this process mean reverts slowly. Engel (2001) from the result on the Table 5, the sum of the root is given as $(0.063)$ a value that is close to unity. This shows that the variance in the world oil price is not stable and volatile but can reverts to its original position.

Table 5: ARCH/GARCH result for Nigeria

\begin{tabular}{lrrr}
\hline Variables & Coefficient & Std Error & Probability \\
\hline C & 0.0047 & $2.90 \mathrm{E}+0.9$ & 0.18123 \\
ARCH(1), $\alpha_{\mathrm{i}}$ & 0.1423 & 0.5514 & 0.3426 \\
GARCH (1), $\beta_{\mathrm{i}}$ & 0.2456 & 3.8624 & 0.0692 \\
\hline
\end{tabular}

\subsubsection{ARCH/GARCH result for Angola}

The volatility test for Angola shows a mean variance of 4.062. The volatility shocks are not persistent since the sum of the roots is less than one and not even closed to unitary. This shows that the variance in the world oil price is stable in Angola but not very volatile unexpectedly and in most occasions reverts quickly to its origin position. This result implies that the variation in the world oil price is not responsible for by the lag of its error term. Therefore, volatility and shock in world oil price are not really as a result of news about volatility and shock from the previous. This confirmed the fact that a major cause of world oil price volatility is speculation around the prices by the agent in the market.

Table 6: ARCH/GARCH result for Angola

\begin{tabular}{lrrr}
\hline Variables & Coefficient & Std Error & Probability \\
\hline C & 0.0462 & $3.80 \mathrm{E}+0.7$ & 0.6211 \\
ARCH(1), $\alpha_{\mathrm{i}}$ & 0.1234 & 0.6621 & 0.0345 \\
GARCH (1), $\beta_{\mathrm{i}}$ & 0.2671 & 3.2456 & 0.0821 \\
\hline
\end{tabular}

\subsubsection{Impulse response function}

VAR (Auto regression) estimates could be employed to determine or trace the effect of one standard deviation shock to one of the innovation current and feature values of endogenous variables.

\subsection{Impact analysis for Nigeria}

The results of impulse response functions are presented in Appendix figure 4.1 From the figure, the response of GDP growth rate to shocks emanating from world oil price volatility is negative and significant from the first quarter and this persisted till the fifth quarter when the response die down till seventh quarter. Thereafter, the response further became negative and significant till the tenth quarter. The implication of this is that world oil price volatility has negative impact on the growth of Nigerian economy during the study period. This has always been confirmed with the macro economic performance in Nigeria either during crude oil price reduction or during oil price increase. For instance, Nigerian economy has been in recession since almost three quarters now because of sudden reduction in global oil price at international oil market in mid-2014

The response of money supply to the shock coming from world oil price was negative and insignificant from first quarter till the fourth quarter. Thereafter, the response became positive and still insignificant till the eight quarter. After this, the response was now oxalating but became positive till the tenth quarter. Looking critically at the results in figure 4.1, the result equally confirms that a standard deviation shock coming from world oil price inflicts negative and significant effects on exchange rate in Nigeria. This conforms with the theoretical prediction. The response of consumer price index to shock coming from world oil price was initially significant and positive from first quarter till fourth quarter but later oscillating toward equilibrium from fifth quarter till seventh quarter. Thereafter, the response further became negative and significant till the tenth quarter. The result in figure 4.1 shows that a standard deviation shock from world oil price has negative but significant impact on real interest rate in Nigeria. The impulse response function maintains an equilibrium level from quarter one up to the 
sixth quarter struggling to rise but the surge was impossible because on inbuilt nature of developing economies particularly Nigeria.

\subsection{Variance decomposition for Nigeria}

In this sub-section, we determine the percentage of variances in each endogamous variable that is determined by the other variables. This assists to provide the amount of influence the endogenous factors exert on each other.

The variance decomposition suggests that world oil price had the highest impact on exchange rate for the entire period of the analysis. It increases steadily and significant over time world oil price responsible for about six percent of shocks to exchange rate in the first quarter and increase to about twenty five percent in the tenth quarter. From the results on Table 6, the growth rate of Gross Domestic Product essentially explains itself for the first five periods of the analysis. Thereafter, world oil price accounted for the largest variations in growth rate of Gross Domestic Product, take for instance almost four percent variation in GDPgr in the first three quarter was from WOP, this increased persistently to almost twenty percent in the tenth quarter. The contribution of real interest rate to variation in GDPgr was not significant average of thirteen percent throughout the analysis. The variations in money supply was explained majorly by growth rate of Gross Domestic Product. GDPgr accounted for about $30 \%$ of the variation in the first quarter, this increased to about forty eight percent in the fifth quarter and increased steadily to about $70 \%$ in the tenth quarter. The contribution of world oil price volatility was significant. The contribution of consumer price index was significant oxillating between five to seven percent within the first and tenth quarter.

Conclusively, the variance decomposition result showed that shock to exchange rate and growth rate of Gross Domestic Product were accounted for twenty-four and twenty two percent for by world oil price volatility. The implication of this is that, Nigeria as a net oil exporter, the naira appreciates when oil price increases and depreciates when oil price falls in international world oil market. This finding is compatible with Iyoha \& Oriraki, (2013), Olomola, (2006) Akpan, (2008).

\subsection{Impact analysis for Angola}

Using the structural vector Autoregressive Distributive model, the impulse Response Functions of Angola was estimated by using quarterly data. The result on figure 4.2 in the appendix shows that one standard deviation shock in oil price has statistically significant, contemporaneous, and positive effects on the growth rate of the Angola economy. This is because the response of GDPgr was positive and significant right from first quarter till the tenth quarter from the analysis, higher oil prices increase output during the period of analysis.

Our VAR analysis in Angola also includes exchange rate, consumer price index, real interest rate and money supply. From the results, the response of exchange rate was positive but not statistically significant. As net oil exporting nation, when price of oil increases at world oil international market, her currency appreciates. The response of money supply was negative but significant from first quarter to the fifth quarter but became positive but still maintain significant level. However, the response of consumer price index was positive and significant right from first quarter till the fifth quarter before it started to become negative and significant till the eight quarter. Thereafter, it started to be positive and insignificant. The response of real interest rate was not significant but before it eventually dies of in the tenth quarter.

\subsection{Variance decomposition for Angola}

The result from IRF corroborates the findings generate from the variance decomposition result. The $15.2 \%$ or the variation in growth ratio of Gross Domestic Product can be explained by world oil price volatility at the end of the fifth quarter. This was followed by the exchange rate that explained fair portion of the growth rate of Gross Domestic Product. Exchange Rate explained almost 14\% variation in GDPgr. Inflation rate equally explained some of this variations. Consumer price index was equally significant and positive almost $5 \%$ till the seventh quarter.

\section{Comparative analysis of the relationship between oil price volatility and macro - economic performance in Angola and Nigeria.}

Angola and Nigeria are the two largest net oil exporting countries in Africa. The empirical analysis started with Stationarity Test. In both countries, the variables of interest were stationary after the first difference. Thereafter, E (GARCH) was used to establish the oil price volatility. It is confirmed from the result that oil price was volatile in both nations. This now enabled us to test for Granger Causality Test. In Nigeria, the Causality that ran between world oil price and macroeconomic variables was bi-directional. That is, world oil price Granger Causes all macroeconomic variables also macroeconomic variables Granger Causes World Oil Price. While in Angola, the direction of Causality was unidirectional. That is, World Oil Price Granger causes only Growth rate of Gross Domestic Product, money supply and Exchange rate but did not Granger Causes Real Interest Rate. The result of both Impulse Response Function and Variance Decomposition were the same in the two countries (Nigeria and Angola). The response of Growth Rate of GDP to shocks emanating from world oil price was positive 
and significant in both countries, the contribution of world oil price to variation in Growth Rate of Gross Domestic was the highest. The implication of this is that an increase in world oil price has positive impact on microeconomic performance but not significant while a decrease in world oil price has negative and significant impact on the macroeconomic performance of these two countries (Nigeria and Angola). The findings of this paper are in Tandem with the previous studies on this topic. See (Olomola, 2006; Iyoha \& Orinka, 2013; Akpan, 2008) and several others.

\section{Summary and conclusion}

This study examined the relationship between oil price volatility and macroeconomic performance in Nigeria and Angola between 1990 and 2014. The study made used of Structural Vector Autoregressive model, E(GARCH) and Granger Causality Test as estimation techniques. The Augmented Dickey fuller (ADF) Test showed that all the variables of interest in both countries were stationary at first difference, that is integrated of order one 1(1). Results from both impulse response function and variance decomposition showed that oil price volatility had marginal impact of Growth Rate of Gross Domestic Product which was used to proxy economic growth. The E (GARCH) result showed that oil price was relatively volatile during the study periods. Also, Pairwise Causality Test showed a bi-directional relationship between oil price and macroeconomic variables in Nigeria, while it showed a unidirectional relationship in Angola. Based on these findings, it is recommend that both nations (Nigeria and Angola) should strengthen their crude oil refining capacity, also, that economic diversification should be encouraged by various governments of these countries to improve their indigenous productive capacity to reduce importation of those goods that could be produced locally.

\section{References}

Akpan E.0, (2009). Oil price shocks and Nigeria's macroeconomic.

Aliyu, S.U.R. (2009). Impact of oil price shock and exchange Rate Volatility on Economic Growth in Nigeria: An Empirical investigation Research Journal of International studies

Ayadi O.F (2005). Oil price fluctuations and the Nigeria economy, OPEC Review: Energy Economic \& Related Issues 29 (3), 1999-217.

Baig, et al. 2007. Domestic petroleum product prices and subsidies: recent developments and reform strategies. International Monetary Fund Working Paper. (Online) Available from: http://www.ksri.or/bbs/files/research 02/wp0771.pdf

Bamisaye, O. A. and Obiyan, A. S. 2006. Policy analysis of oil sector in Nigeria. European Journal of Social Sciences (Online). Available from: http://eurojournals.com/ejss\%203\%201.pdf\#page $=43$

Baumeister, C. and peerman, G. 20089. Source of the volatility puzzle in the crude oil market. (Online). Available from: http://www.feb.ugent.be/FinEco/christaine/documents/BP2_dec09.pdf

Chaudhuri, K., Daniel, B.C. (1998). Long-run equilibrium real exchange rates and oil prices, Economic Letters 58, 231-238.

Darby, M. (1982). The price of oil and world inflation and recession, The American Economic Review 72 (4).

Foderer, J. Peter. "Oil Price Volatility and the Macroeconomy." Journal Macroeconomics, Winter 1996, 18 (1). pp. 1-26.

Hooker, Mark A. "This is what Happened to the oil Price-Economy Relationship." Journal of Monetary Economics, 1996b, 38 (2). pp. 195-213.

Miero, S. and Ramous, P.N. 2010. Dutch disease in Macau: diagnosis and treatment. (Online) Available from: http://www.eefs.eu/conf/Athens/papers/593.pdfokonju, C. (2009). Oil price fluctuation and its effect on growth. Journal of Historical Economics, 2 (5), 15-18

Mork, K. A. (1989). Oil and the macro-economy, when prices go up and down: an extension of Hamilton's results, journal of political Economy 97 (3), 740-744

Mork, P., Oslen, O., \& Mysen, H. (1994). Macroeconomic responses to oil price increases and decreases in seven OECD countries, Energy Journal 15, 15-38

Olaokun, O. (2000). Oil price shock effects on economies of African nations. African Economic journal, 3 (10) 3039

Olomola, P.A., \& Adejumo, A.V. (2006). Oil price shock and macroeconomic activities in Nigeria, International Research Journal of Finance and Economics 3, 28-34.

Omojolaibi, J.A., \& Egwaikhide, F.O. (2013). A panel analysis of oil price dynamics, fiscal stance and macroeconomic effects: the case of some selected African countries. Central Bank of Nigeria Economic and Financial Review. 51 (1).

Oriakhi, D.E., \& Iyoha, D.O. (2013). Oil price volatility and consequences on the growth of the Nigeria Economy: An Examination (1970-2010): Asian economic and financial review, 3 (5): 683-702.

Oriakhi, D.E., \&b Osazee, I.D. (2003). Oil price volatility and its consequences on the growth of the Nigerian economy: An Examination (1970-2010). Asian Economic and financial Review, 3 (5) 683-702. Retrieved from http://aessweb.com/journal-detailed.phpid $=5002$ 
Papapetrou, E. (2001). Oil price shocks, stock market, economic activity and employment in Greece, Energy Econ. 23, 511-532

Pindyck, Robert. “Irreversibility, Uncertainty, and Investment. “ Journal of Economic Literature, September 1991, 29 (3), pp. 110-48.

Rasche, Robert H. and Tantom, John A. Energy resources and potential GDP. Federal Reserve Bank of St. Louis Review, June 1977b, pp 10-24.

Rasmussen, T.N., \& Roitman, A. (2011). Oil shocks in a global Perspective: Are they really that Bad? IMF Working Paper No: WP/11/194.

Tatom, J.A (1993). Are there useful lessons from the 1990-1991 oil price shock"? The Energy Journal 14 (4), 129150.

\section{Appendix 2: Impulse Response VAR Model for Angola}
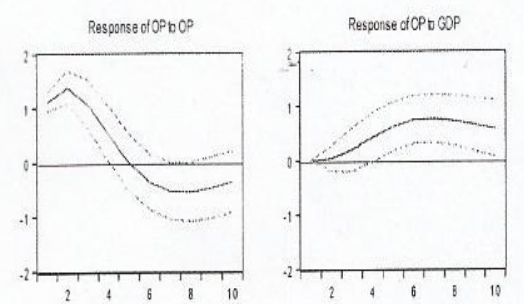

Response to Cholesky One S.D. Innovations \pm 2 S.E
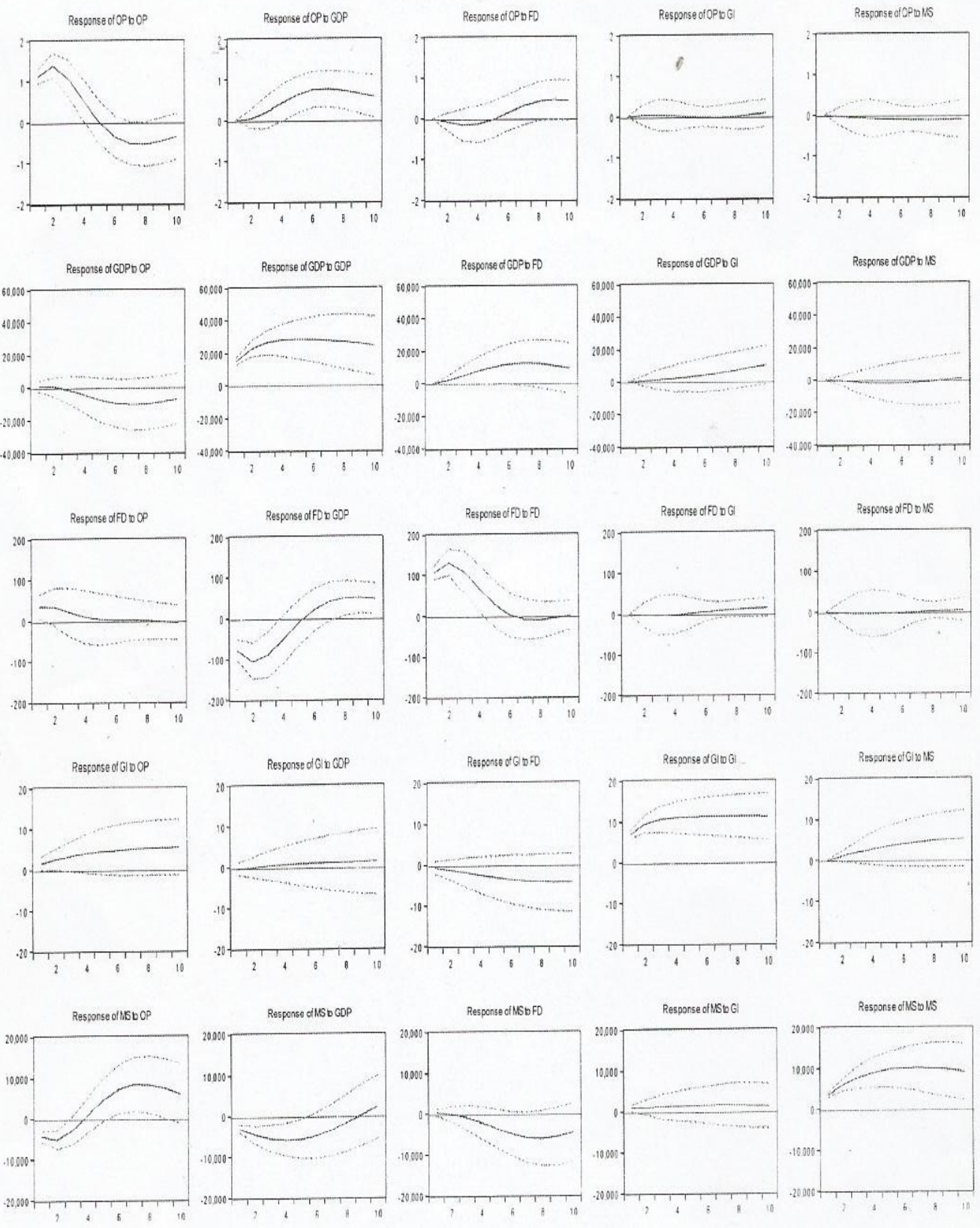


\section{Appendix 5: Impulse Response VAR Model for Nigeria}
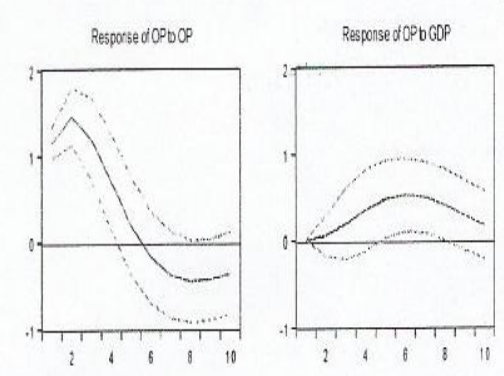

Resporse to Chileshy Gre S.D. Inourions t2S.E.
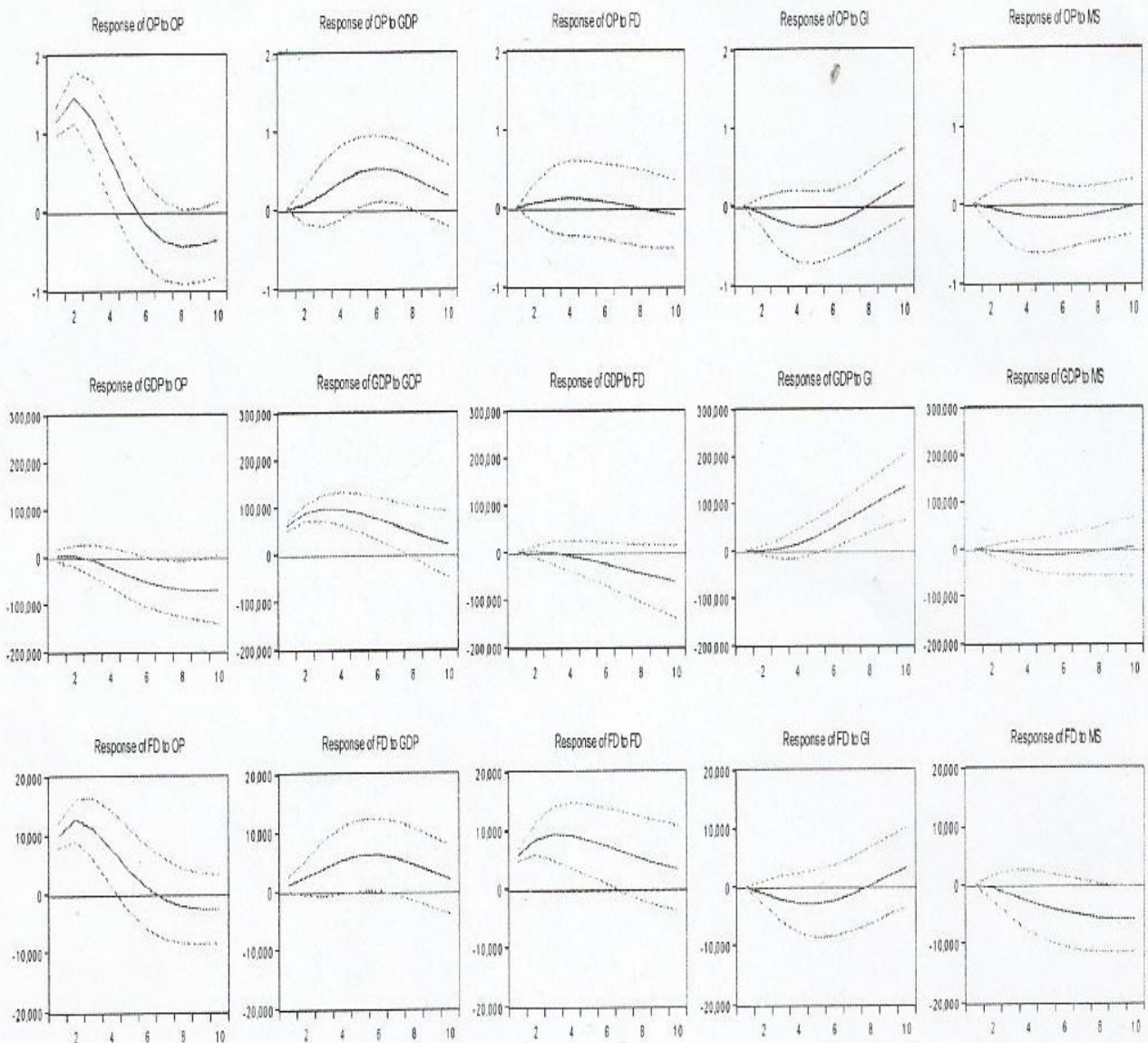

Response of G to $00^{\circ}$
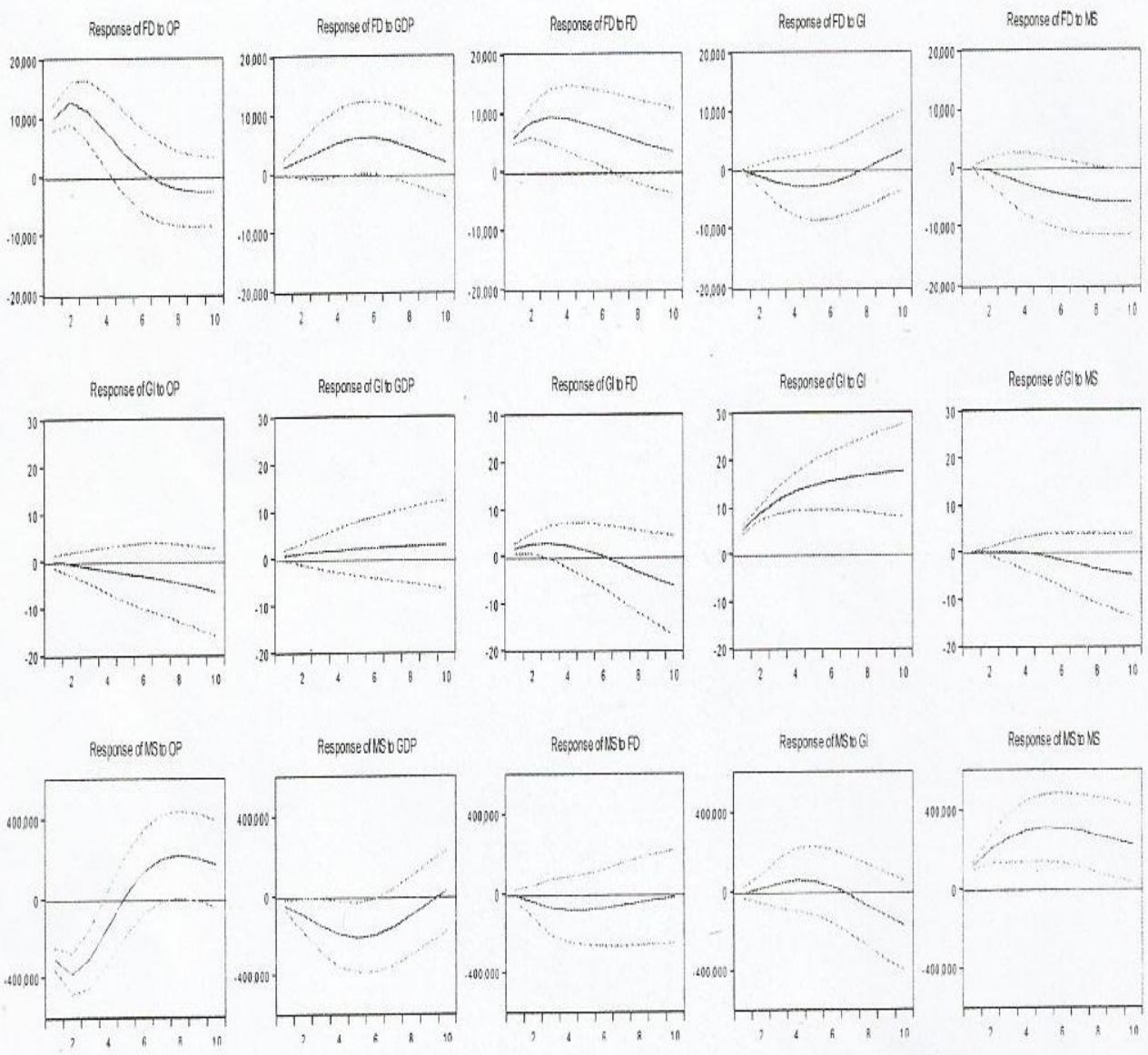